\title{
Development of PowToon-Based Physics Learning Media on Atomic Nucleus Materials for Class XII Senior High School
}

\author{
M. Nor ${ }^{* 1)}$, Mitri Irianti ${ }^{2}$, Suci Dila Melani ${ }^{3)}$ \\ 1,2,3) Physics Education University of Riau \\ e-mail: m.nor@lecturer.unri.ac.id \\ mitri.irianti@lecturer.unri.ac.id \\ suci.dila1050@student.unri.ac.id
}

\begin{abstract}
Online service in the form of the Powtoon application can be used to develop physics learning media with presentations that have very interesting animation features. The purpose of this research is to produce a learning media product in the form of a compact disk (CD) on the subject of the atomic nucleus in the learning process of class XII high school students. The research method uses Research and Development with the ADDIE model (Analysis, Design, Development, Implementation, and Evaluation) which is modified only to the development stage. Based on the results of the validation test on the content aspect obtained $90 \%$, the design aspect 83\%, the pedagogic aspect 87\%, and the ease of use aspect $84 \%$. The results of this research indicate that the learning media using the Powtoon application on the atomic nucleus material is declared valid. Thus the Powtoon application-based learning media is declared feasible to be used as a learning media on atomic nucleus material in class XII SMA.
\end{abstract}

Keywords: Powtoon application, atomic nucleus, learning media. 


\title{
Pengembangan Media Pembelajaran Fisika Berbasis Powtoon pada Materi Inti Atom untuk Kelas XII SMA
}

\author{
M. Nor ${ }^{* 1)}$, Mitri Irianti ${ }^{2}$, Suci Dila Melani ${ }^{3)}$ \\ 1,2,3) Pendidikan Fisika Universitas Riau
}

\begin{abstract}
Abstrak
Layanan online berupa aplikasi Powtoon dapat digunakan untuk mengembangkan media pembelajaran fisika dengan paparan yang memiliki fitur animasi sangat menarik. Tujuan penelitian ini untuk menghasilkan produk media pembelajaran berbentuk compact disk (CD) pada pokok bahasan inti atom dalam proses pembelajaran siswa kelas XII SMA. Metode penelitian mengunakan Research and Development dengan model ADDIE (Analysis, Design, Development, Implementation, and Evalution) yang dimodifikasi pelasanaannya hanya sampai pada tahap pengembangan. Berdasarkan hasil uji validasi pada aspek isi diperoleh $90 \%$, aspek perancangan $83 \%$, aspek pedagogik $87 \%$, dan aspek kemudahan dalam penggunaan $84 \%$. Hasil penelitian ini menunjukkan bahwa media pembelajaran menggunakan aplikasi Powtoon pada materi inti atom dinyatakan valid. Dengan demikian media pembelajaran berbasis aplikasi Powtoon dinyatakan layak digunakan sebagai media pembelajaran pada materi inti atom di kelas XII SMA.
\end{abstract}

Kata Kunci: aplikasi Powtoon, inti atom, media pembelajaran

\section{Pendahuluan}

Mengingat fakta bahwa pendidikan harus mengembangkan kemampuan kognitif, afektif, dan psikomotor, itu adalah salah satu instrumen terpenting untuk pengembangan sumber daya manusia. Akibatnya, penyelenggaraan pendidikan membutuhkan perencanaan dan implementasi yang matang untuk mencapai hasil yang diharapkan sejauh mungkin.

Pendekatan ilmiah untuk pembelajaran yang tergabung dalam kurikulum 2013 digunakan di semua tingkat pendidikan. Siswa harus dapat secara aktif mengembangkan hukum, gagasan, atau prinsip melalui proses observasi, mengartikulasikan masalah, menyarankan atau merumuskan hipotesis, mengumpulkan data dengan berbagai metodologi, mengevaluasi data, membuat kesimpulan, mengkomunikasikan konsep, hukum, dan prinsip (Permendikbud, 2013).

Menurut Kurikulum 2013, instruktur harus bertindak sebagai fasilitator, membantu siswa dalam menyelesaikan tantangan pembelajaran selama kegiatan belajar. Persepsi siswa terhadap proses pembelajaran saat mereka maju melalui sekolah memiliki dampak signifikan pada kemampuan mereka untuk mencapai tujuan pendidikan. Merupakan tanggung jawab guru, sebagai pendidik yang terlibat langsung dalam pelaksanaan pembelajaran, untuk memberikan kondisi belajar kepada siswa yang akan memungkinkan mereka belajar secara optimal guna mencapai hasil belajar yang memuaskan (Slameto, 2003).

Upaya pemerintah untuk meningkatkan pendidikan perlu revisi yang konstan, khususnya dalam kurikulum dari KTSP hingga Kurikulum 2013. K13 memiliki banyak keunggulan dibandingkan KTSP, yang memiliki sejumlah kelemahan. Dalam rangka mengatasinya, maka dilakukan reformasi melalui K13 yang mengakibatkan K13 berganti nama menjadi Revisi K13. Namun, banyak sekolah yang terus memanfaatkan K13 dari perubahan kurikulum KTSP, meskipun ada penyesuaian (Mafia \& Suci, 2017).

Media pembelajaran telah berkembang menjadi persyaratan mutlak dalam proses pembelajaran. Setiap media yang dapat dimanfaatkan untuk mentransfer pesan, memancing pikiran dan perasaan, menarik perhatian siswa, dan meningkatkan kesiapan mereka untuk berpartisipasi dalam proses pembelajaran disebut sebagai "media" (Angkowo \& Kosasih, 2007). Seperti yang dijelaskan oleh Munir (2013), istilah 
multimedia, yang biasa digunakan dalam pendidikan saat ini, memberikan gambaran sistem komputer dimana semua jenis media, termasuk teks dan grafik serta audio dan suara, animasi, dan video, terkandung dalam satu model perangkat lunak yang memberikan atau menggambarkan program pendidikan.

Fisika sebagai cabang ilmu pengetahuan alam (IPA) yang diajarkan disemua tingkatan dari sekolah menengah ke perguruan tinggi dan membutuhkan pemahaman menyeluruh tentang ide-ide mendasar. Inti Atom adalah salah satu materi fisika yang dapat dipelajari siswa SMA kelas XII menggunakan aplikasi Powtoon, yang merupakan salah satu topik pembahasan dalam materi ini. Selama ini guru bidang fisika masih banyak berperan sentral dalam proses pembelajaran, sehingga siswa tidak dapat berfungsi secara mandiri. Hal ini berbeda dengan pelaksanaan kurikulum 2013, yang mengambil pendekatan ilmiah, dimana guru berperan sebagai fasilitator siswa, karena pendekatan ini melatih siswa untuk lebih aktif dan mengembangkan pemikiran mandiri (Permendikbud, 2013). Secara keseluruhan, bahan Inti Atom bersifat abstrak dan menuntut pengetahuan mendalam. Oleh karena itu, siswa harus mencurahkan perhatian yang lebih besar untuk mengikuti proses pembelajaran, agar konsep yang dinyatakan dapat dipahami oleh mereka. Cara yang digunakan dalam menjelaskan konsep dapat dipahami oleh siswa dengan baik. Akibatnya, untuk memahami konsep abstrak, perlu untuk memvisualisasikannya sedemikian rupa, sehingga muncul seolah-olah ada di dunia nyata.

Perlu dilakukan pekerjaan untuk membangun media pembelajaran yang akan menarik perhatian siswa dan memudahkan proses berpikir mereka, sehingga dapat memahami makna materi yang disampaikan. Siswa juga dapat diajarkan bagaimana menjadi mandiri melalui metode ini. Menurut Azhar (2011), penggunaan media dapat membuat subjek yang rumit disampaikan kepada siswa lebih mudah dimengerti oleh mereka. Media adalah teknologi yang digunakan untuk mengkomunikasikan konten pesan kepada penerima pesan yang sebagian besar adalah siswa. Karena visualisasi materi dapat dilihat lebih jelas dan menarik ketika media instruksional digunakan, karena penggunaan media instruksional sangat penting untuk penyampaian informasi.

Media Powtoon adalah salah satu program yang berpotensi untuk diubah menjadi media pembelajaran yang menarik di masa depan. Menggunakan Powtoon dapat membuat presentasi yang mencakup berbagai fitur animasi menarik seperti: animasi tulisan tangan, animasi kartun, dan efek transisi yang semarak, yang semuanya dapat disesuaikan dengan pengaturan garis waktu yang relatif sederhana. Program ini dapat memuat animasi video dan lampu kilat serta lebih responsif terhadap input pengguna daripada media lain, seperti presentasi powerpoint atau keynote. Beberapa aspek kelayakan media pembelajaran dapat dikaji, antara lain aspek desain, aspek pedagogik, aspek konten, aspek kemudahan penggunaan, aspek tampilan, dan aspek pemrograman. Faktor desain dan pedagogis adalah salah satu pertimbangan paling penting.

Hasil studi ke dalam topik tentang subjek struktur atom perlu menghasilkan media pembelajaran berbasis Powtoon. Dalam situasi belajar mengajar, guru tidak akan kesulitan dalam memasukkan media ini ke dalam pelajaran mereka dan siswa akan memahami konsep pembelajaran di sekolah secara lebih lengkap. Keberhasilan mencapai tujuan pendidikan sangat tergantung pada bagaimana siswa memahami proses pembelajaran, karena Kurikulum siswa 2013 memiliki tujuan memberdayakan pendidik untuk bertindak.

Fatmala, et al. (2016) menyatakan hasil teknik wawancara mengungkapkan bahwa hasil pembelajaran kognitif siswa dalam materi inti atom dan radioaktivitas masih terbilang buruk, dengan hanya 45,5 persen mencapai hasil yang memuaskan.

Sebagai fasilitator yang membantu siswa dalam menyelesaikan tantangan pembelajaran sambil berpartisipasi dalam kegiatan belajar. Guru adalah pendidik yang membangun lingkungan belajar dimana siswa dapat belajar dengan potensi maksimum mereka untuk mencapai hasil belajar yang memuaskan. Tentu saja hasil belajar yang memuaskan dicapai dengan melibatkan lingkungan belajar (Slameto, 2003). Menurut pendapat Roza et al. (2019), bahwa teknik flipping classroom dapat meningkatkan minat dan keterlibatan siswa dengan melengkapi penggunaan media Powtoon untuk pembelajaran. 
Generasi milenial adalah generasi yang akrab dengan dunia digital. Di era digital, diharapkan semua orang akrab dengan teknologi disemua kalangan. Sistem pendidikan Indonesia menerapkan kurikulum 2013 sebagai titik awal. Semua level diimplementasikan menggunakan pendekatan ilmiah untuk memastikan keberhasilan. Mencermati dan mengidentifikasi masalah, menyarankan atau membentuk hipotesis, mengumpulkan data menggunakan berbagai metodologi, menganalisis data dan menghasilkan kesimpulan adalah semua langkah dalam proses membangun konsep, hukum, atau prinsip (Permendikbud, 2013).

Kurikulum 2013, mengharuskan instruktur sebagai fasilitator dalam proses pembelajaran, tetapi dalam praktiknya guru tetap penting dalam proses pembelajaran, sehingga siswa tidak dapat berperan secara independen dari guru mereka. Mereka juga menyatakan bahwa bahan Inti Atom umumnya abstrak dan membutuhkan pemahaman yang mendalam dari pihak siswa. Oleh karena itu, disarankan siswa untuk lebih berkonsentrasi mengikuti proses pembelajaran, agar konsep yang dijelaskan dapat dipahami oleh siswa setelah jumlah waktu yang cukup di kelas. Akibatnya, visualisasi dibangun sedemikian rupa sehingga tampak nyata. Selain itu, menurut Inesa (2015) dalam kategori media pembelajaran, hasil yang diperoleh melalui penggunaan perangkat lunak studio media AutoPlay yang diproduksi sangat baik, menunjukkan bahwa media yang dihasilkan cocok untuk digunakan sebagai media pembelajaran.

Azhar (2011) menegaskan bahwa penggunaan media dapat membantu menyelesaikan kompleksitas materi yang diberikan kepada pengguna. Siswa adalah penerima pesan yang dikirim melalui media, yang merupakan alat yang digunakan untuk mengirimkan pesan. Penggunaan media pembelajaran diperlukan untuk menyampaikan subjek karena visualisasi memungkinkan materi untuk dilihat lebih jelas dan menarik dari pada yang seharusnya. Media pembelajaran, seperti yang dibuat menggunakan program aplikasi Powtoon, adalah salah satu contohnya.

Melakukan upaya membangun media pembelajaran yang menarik perhatian siswa akan memudahkan mereka untuk menyerap hal-hal abstrak dan akan mencegah mereka jenuh selama pendidikan mereka. Menggunakan aplikasi Powtoon, dapat membangun eksposur yang mencakup berbagai karakteristik animasi yang menarik, seperti tulisan tangan, animasi kartun, dan efek transisi yang sangat jelas, selain cukup mudah digunakan dalam hal waktu (Adam, 2015).

Kemajuan teknologi informasi digunakan dalam setiap aspek kehidupan manusia, termasuk pendidikan. Salah satu diantaranya penggunaan teknologi sebagaimana dalam kajian Nor et al. (2021), yang menggunakan aplikasi Powtoon dalam materi pemanasan global umumnya abstrak dan membutuhkan pemahaman yang mendalam. Media yang digunakan lebih sederhana untuk memahami gagasan, terutama bahan pembelajaran yang bersifat abstrak menghasilkan penampilan yang tampaknya realistis. Melakukan upaya merancang media pembelajaran yang dapat menarik perhatian siswa untuk memfasilitasi proses kognitif siswa untuk memahami arti konten yang disajikan dan menghasilkan siswa yang mandiri mungkin berbuah usaha. Aplikasi Powtoon merupakan salah satu program yang berpotensi untuk diubah menjadi media pembelajaran yang menarik di masa depan. Dalam penyelidikan ini, aplikasi PowToon ditemukan lebih efisien daripada media lain, seperti Powerpoint, dapat memuat animasi video dan flash dan beroperasi lebih lancar. Ini adalah aspek unik dari penelitian ini, karena menggabungkan animasi video pembelajaran dengan film lain untuk membuat subjek yang disajikan terasa lebih otentik.

Paradigma pembelajaran kelas yang terbaik untuk materi termodinamika dikembangkan menggunakan film animasi berbasis Powtoon, menurut penelitian Basyari et al. (2012) yang secara khusus mengatakan bahwa fisika inti (inti atom dan radioaktivitas) adalah salah satu topik dalam pembelajaran fisika inti dan radioaktivitas yang bersifat abstrak, membutuhkan imajinasi yang lebih besar dari pihak guru untuk mengkomunikasikan topik fisika inti kepada siswa.

Dengan tersedianya bahan ajar berrupa media video Powtoon, bermanfaat bagi siswa untuk digunakan sebagai bahan ajar. Para peneliti juga menemukan bahwa program Powtoon dapat digunakan untuk membuat film dari berbagai jenis bahan. Media pembelajaran dengan aplikasi Powtoon yang valid dikembangkan berdasarkan informasi yang 
diperoleh dalam penelitian pengembangan ini dan untuk digunakan mengajarkan konsep tentang materi inti atom kepada siswa di kelas XII SMA, sehingga guru tidak kesulitan dalam mengajar dengan media ini dan membantu siswa memahami konsep pembelajaran di sekolah.

Berdasarkan penjelasan yang telah diuraikan, maka tujuan dari penelitian ini adalah untuk menghasilkan suatu media pembelajaran menggunakan aplikasi Powtoon yang valid sebagai media mengajar siswa di kelas XII SMA pada materi fisika inti.

\section{Metode Penelitian}

Program Studi Fisika di FKIP Universitas Riau sebagai tempat melakukan penelitian pengembangan media pembelajaran berbasis aplikasi Powtoon pada tahun 2021. Penelitian ini menggunakan metode research and Development (R\&D), model perancangan media pembelajaran ADDIE (Analyze, Design, Development, Implementation and Evaluation) sebagai model desain yang cocok untuk pengembangan media pembelajaran fisika materi inti atom untuk siswa sekolah Menengah Atas (SMA) di kelas XII. Media yang dibuat menggunakan program Powtoon. (Sugiyono, 2015).

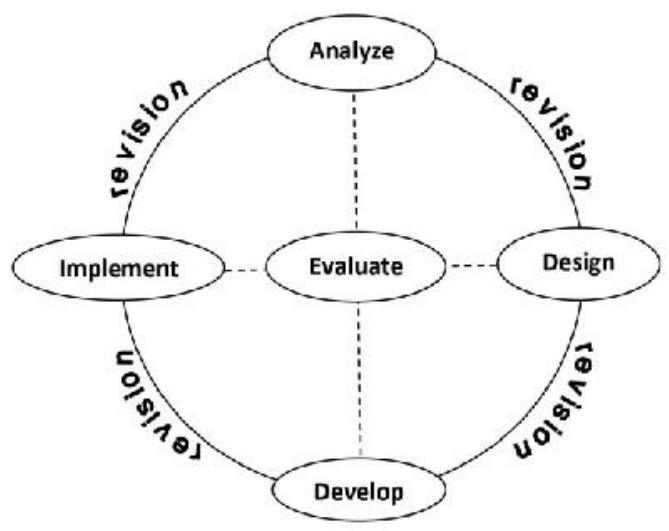

Gambar 1. Pengembangan media pembelajaran model ADDIE (Branch, 2009).

Prosedur penelitian dan pengembangan dilakukan hanya sampai pada tahap pengembangan suatu produk. Menurut skema pengembangan penelitian model ADDIE sebagaimana Gambar 1, tahap analisis dibagi menjadi dua bagian: analisis kebutuhan dan analisis tugas dan topik. Ada lima tahapan desain, yaitu: pembelajaran tujuan (objective learning), tatanan pembelajaran, memilih strategi pembelajaran, dan strategi evaluasi, dalam urutan kepentingan tersebut. Pengembangan konten, pembuatan story board, dan produksi media, semuanya termasuk dalam tahap pengembangan (development).

Penelitian ini menggunakan alat lembar validasi, yang mencakup validasi ahli materi dan validasi ahli media, untuk mengumpulkan data, yang diberikan menggunakan tautan formulir google.form. Dalam penelitian ini, data dikumpulkan melalui validasi tim validator dan dianalisis menggunakan persamaan (1) (Inesa, 2015).

$$
P=100(\%) \frac{\sum \mathrm{Ja}}{\sum \mathrm{N} \quad \mathrm{t}_{\mathrm{l}} \mathrm{V}}
$$

Keterangan:

PV = Penilaian validator

¿jawaban validator $=$ Total jawaban validator Enilai tertinggi v. $=$ Total nilai tertinggi validator

Ketentuan validasi media berdasarkan informasi dari validator menggunakan ketentuan menurut Tabel 1.

Tabel 1. Skala perentase dan validasi media

\begin{tabular}{ll}
\hline Persentase & Kategori \\
\hline $80-100$ & Valid / Layak \\
$60-79$ & Cukup Valid /Cukup Layak \\
$50-59$ & $\begin{array}{l}\text { Kurang Valid / } \\
\text { Kurang Layak } \\
\text { Tidak Valid / } \\
\text { Tidak Layak }\end{array}$ \\
\hline
\end{tabular}

Sumber: (Ridwan, 2011).

\section{Hasil dan Pembahasan}

Model pengembangan ADDIE, yang memiliki lima tahap, digunakan dalam pembuatan media pembelajaran berbasis Powtoon. Tahap pertama meliputi analisis materi dan analisis media pembelajaran. Keduanya dilakukan pada langkah analisis 
proses. Pengumpulan teori tentang materi inti atom adalah semacam aktivitas analisis material yang dilakukan dalam kegiatan ini. Dengan menggunakan aplikasi Powtoon pada materi inti atom. Perancangan media pembelajaran bagi siswa SMA XII dalam meningkatkan kemampuan kognitif siswa. Langkah pertama dalam proses pengembangan adalah tahap analisis terhadap siswa, kurikulum, dan materi sesuai kurikulum 2013. Media pembelajaran tentang bahan inti atom dikembangkan sebagai hasil dari penelitian ini. Langkah ini telah mencakup penyelesaian penilaian kebutuhan, analisis kurikulum, dan analisis material. Atas dasar literatur yang relevan dengan penelitian ini, ditentukan bahwa ada kebutuhan untuk mengevaluasinya. Setelah itu,

Kurikulum dikaji sesuai dengan Permendikbud No.37 tahun 2018, yang berfokus pada kompetensi dasar pengetahuan 3.10 dan kompetensi dasar keterampilan 4.10. Selain itu, silabus digunakan untuk membuat referensi ke analisis dan interpretasi bahan. Bahan yang dipertimbangkan termasuk damal pembuatan media yaitu: partikel konstituen inti atom, isotop, isoton, isobar, cacat massal, dan energi ikat inti. Bagian tentang radioaktivitas membahas sinar radioaktif, aktivasi inti, paruh waktu, dan dosis penyerapan. Reaksi fusi dan reaksi fisi dibahas secara rinci dalam bab tentang reaksi inti. Membahas tentang aplikasi radiasi dibidang kesehatan, industri, pertanian, dan reaktor nuklir selama percakapan radioaktivitas. Terdapat ada dua pertemuan tentang inti atom dan radioaktivitas. Wawancara dengan guru mata pelajaran fisika dilakukan selama studi media pembelajaran dilakukan.

Tahap kedua adalah desain keseluruhan media Powtoon pada konten inti atom, serta pengembangan instrumen lembar validasi dan kuesioner. Pada tahap ketiga pengembangan, media pembelajaran fisika yang memanfaatkan Powtoon dibuat untuk materi inti atom, dan validasi media dilakukan oleh validator setelah tahap pengembangan dilakukan. Prosedur validasi diulang minimal dua kali untuk memastikan bahwa media pembelajaran yang valid diperoleh, dan validator menentukan apakah media pembelajaran yang valid harus diberi nilai atau poin. Terhadap kuesioner dan analisis data, serta tanggapan siswa terhadap media pembelajaran Powtoon tentang materi inti atom telah dianggap memuaskan.

Tahap I dikhususkan untuk analisis (analyze), dan ada analisis tahap yang diselesaikan, yang mencakup pemeriksaan persyaratan, tugas, dan tema. Operasi analisis dalam bentuk perakitan hipotesis yang berkaitan dengan subjek inti atom sedang dilakukan. Menurut temuan wawancara dengan salah satu guru fisika di sekolah menengah atas.

Tahap II adalah desain, dan selama tahap ini, pembelajaran objektif (tujuan pembelajaran), urutan pembelajaran, memilih strategi pembelajaran, dan strategi penilaian, serta pengembangan lembar validasi, instrumen, dan kuesioner, selesai. Tahap III adalah implementasi.

Tahap III adalah pengembangan, dan selama tahap inilah pengembangan konten, pengembangan papan cerita, dan produksi media berlangsung. Selain itu, pengembangan animasi bergerak seperti Gambar 2. Yang menunjukkan grafik presentasi validasi pada media Powtoon.

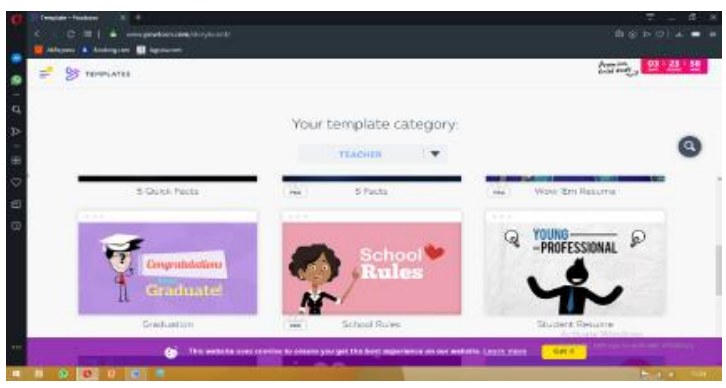

(a)

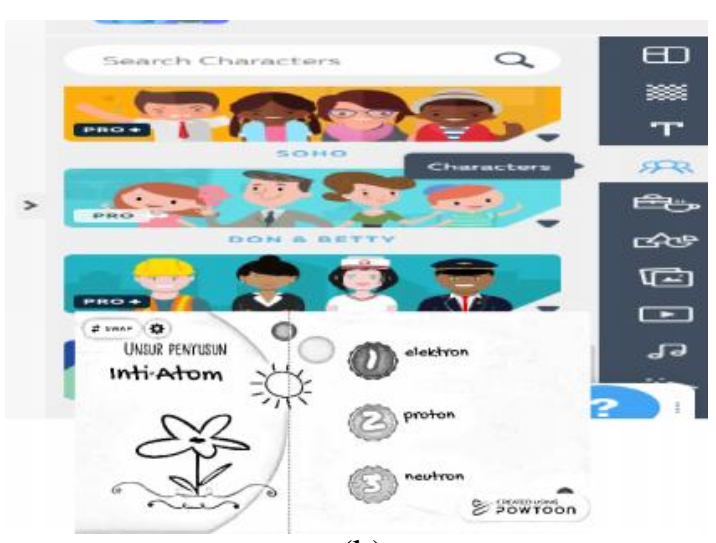

(b)

Gambar 2. Pengembangan Media PowToon a) Website PowToon

b) Animas Bergerak c) Inti Atom 
Data temuan penelitian dikumpulkan melalui hasil validasi dari tim validator yang terdiri dari tiga Orang ahli dari dosen yang berpengalaman di bidangnya, yang masingmasing mengisi validasi pengembangan media Powtoon. Proses validasi diulang dua kali untuk memastikan bahwa media pembelajaran yang valid diperoleh dan bahwa validator memutuskan untuk menambah nilai pada media pembelajaran yang telah ditemukan sah. Hasil ini didukung oleh hasil kajian Mafia \& Suci (2017) menggunakan aplikasi Powtoon dengan pendekatan saitifik. Para ahli dibidang media dan ahli materi telah mengevaluasi empat komponen.

Data hasil penelitian hasil validasi ahli materi dan ahli media ditunjukkan pada Gambar 3 yang menunjukkan nilai persen diatas $80 \%$ dengan kategori valid yang selasar dengan hasil kajian Nor et al. (2021) yang menghasilkan media Powtoon dalam pembelajaran fisika.

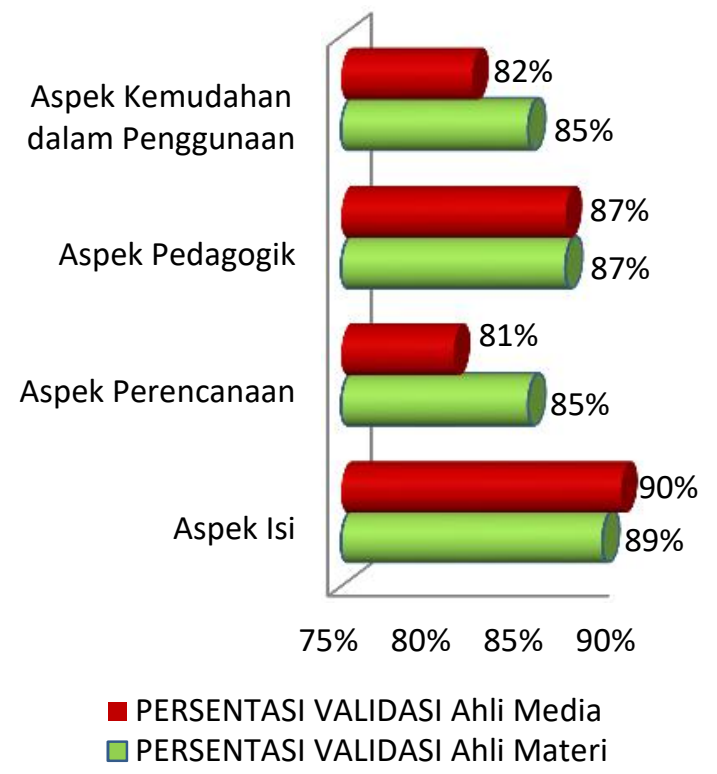

Gambar 3. Grafik persentase validasi pada media Powtoon.

Berdasar grafik pada Gambar 3, diperoleh aspek perencanaan, aspek kemudahan dalam pengunaan dan aspek isi dari validasi ahli media degan ahli materi tidak terlalu jauh penyimpangan sekitar 3\%, 4\% dan 9\%, artinya dari validasi ke empat aspek tersebut dari validator ahli media dan validator materi, menyatakan media Powtoon yang digunakan sesuai dengan materi pembelajaran yang diajarkan.

Hasil rekap penilaian masing-masing komponen diperoleh persentase rata-rata dari kedua aspek validasi ahli dan validasi materi perbedaannya berdasarkan persentase rata-rata komponen atau ke 4 aspeknya tersebut sekitar $0.05 \%$. lebih jelasnya aspek atau komponen yang diteliti diperlihatkan pada Tabel 2. Tabel 2 menunjukkan peringkat rata-rata untuk masing-masing dari empat komponen pengembangan media dinyatakan dalam kategori valid.

Tabel 2. Kategori kevalidan media

\begin{tabular}{llll}
\hline No & $\begin{array}{c}\text { Jenis } \\
\text { Komponen }\end{array}$ & $\begin{array}{l}\text { Rata- } \\
\text { rata }\end{array}$ & Kategorisasi \\
\hline 1. & $\begin{array}{l}\text { Komponen } \\
\text { Isi }\end{array}$ & $90 \%$ & Valid \\
2. & $\begin{array}{l}\text { Komponen } \\
\text { Perencanaan } \\
\text { Komponen } \\
\text { Pedagogik }\end{array}$ & $83 \%$ & Valid \\
4. & $\begin{array}{l}\text { Komponen } \\
\text { Kemudahan } \\
\text { Dalam } \\
\text { Penggunaan }\end{array}$ & $84 \%$ & Valid \\
\hline Persentase Rata-rata & $86 \%$ & Valid \\
\hline
\end{tabular}

Berdasarkan Tabel 2 pengembangan media dari komponen isi, perencanaan, pedagogik dan kemudahan dinyatakan valid dengan kategori rata-rata $86 \%$. Sehingga media Powtoon ini layak digunakan dalam pembelajaran di sekolah untuk materi inti atom dan radioaktif.

\section{Kesimpulan}

Pembutan media pembelajaran berbasis Powtoon pada materi inti atom didasarkan pada model pengembangan Addie, yang mengadaptasi langkah, yaitu analisis, desain, dan pengembangan. Tahapan pelaksanaan dan penilaian belum selesai. Berdasarkan evaluasi validator dan analisis data yang telah dilakukan. Media pembelajaran menggunakan aplikasi Powtoon pada materi inti atom dinyatakan memenuhi syarat sebagai media pembelajaran dan masuk dalam kategori valid. 


\section{Daftar Pustaka}

Adam, S. (2015). Pemanfaatan Media Pembelajaran berbasis teknologi informasi bagi siswa kelas X SMA. CBIS Journal, 3(2), 78-90.

Angkowo \& Kosasih. (2007). Optimalisasi Media Pembelajaran. Jakarta: PT. Grasindo.

Azhar, A. (2011). Media Pembelajaran. Jakarta: PT Raja Grafindo Persada.

Basyari, A., Sunarya, \& Bambang. (2012). Pengembangan Media Pengembangan Fisika Berbasis Adobe Flash untuk Menjelaskan Fisika Inti dan Radioaktivitas untuk SMA Kelas XII. Prosiding Seminar Nasional Fisika. 9 Juni 2012. FMIPA UNJ, Jakarta.

Branch, R. M. (2009). Instructional Design: The ADDIE Approach. Athens: Springer.

Fatmala, R. I, Dwijannati, \& Astuti. (2016). Penerapan Model Double Loop Problem Solving Menggunakan Detektor Geiger Muller untuk Meningkatkan Hasil Belajar Kognitif. Artikel. Fisika UNS, Semarang.

Inesa, W. (2015). Pengembangan Media Pembelajaran Autoplay Media Studio pada Mata Pelajaran Perekayasaan Sistem Audio di SMK Negeri 3 Surabaya. Jurnal Pendidikan Teknik Elektro. 4(3).http://ejournal.unesa.ac.id.

Mafia, S., \& Suci, R. (2017). Pengembangan Media Pembelajaran Powtoon
Pengamatan dalam Implementasi Pendekatan Saintifik Pembelajaran dasardasar sebagai bahan perbankan. Jurnal Pendidikan Ekonomi, 8(3), 101-108.

Munir. (2013). Multimedia dan Konsep Aplikasi Dalam Pendidikan. Bandung: Penerbit Alfabeta.

Nor, M., Zuhdi, \& Asbiah. (2021). The Development of learning Media Based on Powtoon in global warming materials for Class XI High School. Journal of Education Sciences, 5(2), 278-286.

Permendikbud. (2013). Peraturan Menteri Pendidikan dan Kebudayaan Republik Indonesia Nomor 65 Tahun 2013 Tentang Standar Proses Pendidikan Dasar dan Menengah. http://Hukor. kemendikbud.go.id (Diakses 15 April 2020).

Ridwan. (2011). Skala Pengukuran VariabelVariabel Penelitian. Bandung: Alfabeta.

Rosa, H., Dwi, S., \& Suritno, F. (2019). The Development of Learning videos on Powtoon based work and energy topics to support flipped classroom learning, IOSR Jurnal of research \& Method in Education. Yogyakarta.

Slameto. (2003). Belajar dan Faktor-faktor yang mempengaruhinya. Jakarta: Rineka Cipta.

Sugiyono. (2015). Metode Penelitian Kuantitatif, Kualitatif dan $R \& D$. Bandung: Alfabeta. 